\title{
Impossible Antecedents and Their Consequences: Some Thirteenth-Century Arabic Discussions
}

\section{Citation}

El-Rouayheb, Khaled. 2009. Impossible antecedents and their consequences: Some thirteenthcentury Arabic discussions. History and Philosophy of Logic 30(3): 209-225.

\section{Published Version}

doi:10.1080/01445340802447905

\section{Permanent link}

http://nrs.harvard.edu/urn-3:HUL.InstRepos:8141466

\section{Terms of Use}

This article was downloaded from Harvard University's DASH repository, and is made available under the terms and conditions applicable to Open Access Policy Articles, as set forth at http:// nrs.harvard.edu/urn-3:HUL.InstRepos:dash.current.terms-of-use\#OAP

\section{Share Your Story}

The Harvard community has made this article openly available.

Please share how this access benefits you. Submit a story.

\section{Accessibility}


Impossible antecedents and their consequences: some thirteenth-century Arabic discussions

\author{
KHALED EL-ROUAYHEB \\ ASSISTANT PROFESSOR OF ISLAMIC INTELLECTUAL HISTORY \\ HARVARD UNIVERSITY \\ NEAR EASTERN LANGUAGES \& CIVILIZATIONS \\ 6 DIVINITY AVENUE \\ CAMBRIDGE, MA 02138 \\ PHONE: 617-495-1681 \\ FAX: 617-496-8904 \\ E-MAIL: kel@fas.harvard.edu
}




\section{ABSTRACT}

The principle that a necessarily false proposition implies any proposition, and that a necessarily true proposition is implied by any proposition, was apparently first propounded in twelfth century Latin logic, and came to be widely, though not universally, accepted in the fourteenth century. These principles seem never to have been accepted, or even seriously entertained, by Arabic logicians. In the present paper I explore some thirteenth century Arabic discussions of conditionals with impossible antecedents. The Persian-born scholar Afdal al-Dīn al-Khūnajī (d.1248) suggested the novel idea that two contradictory propositions may follow from the same impossible antecedent, and closely related to this point, he suggested that if an antecedent implied a consequent, then it would do so no matter how it was strengthened. These ideas led him, and those who followed him, to reject what has come to be known as 'Aristotle's thesis' that nothing is implied by its own negation. Even these suggestions were widely resisted. Particularly influential were the counter-arguments of Nașīr al-Dīn al-Tūṣī (d.1274). 
Impossible antecedents and their consequences: some thirteenth-century Arabic discussions

The principle that a necessarily false proposition implies any proposition, and that a necessarily true proposition is implied by any proposition, was apparently first propounded in twelfth century Latin logic, and came to be widely, though not universally, accepted in the fourteenth century. ${ }^{1}$ These principles seem never to have been accepted, or even seriously entertained, by Arabic logicians. In the present paper I explore some thirteenth century Arabic discussions of conditionals with impossible antecedents. Some logicians of the period suggested the novel idea that two contradictory propositions may follow from the same impossible antecedent, and closely related to this point, they suggested that if an antecedent implied a consequent, then it would do so no matter how it was strengthened. These ideas led them to reject what has come to be known as 'Aristotle's thesis' that nothing is implied by its own negation. Even these suggestions were, as we shall see, widely resisted.

\footnotetext{
1 See Martin 1987; Martin 1986; and the contributions by K. Iwakuma, J. Spruyt, A. d'Ors, and S. Read in K. Jacobi 1993.
} 
Avicenna (d.1037) held the following two conditionals to be logically equivalent:

(1) Always (Kullama): If Every A is B then Every $\mathrm{J}$ is $\mathrm{D}$

(2) Never (Laysa al-batta): If A is B then Not Every $\mathrm{J}$ is D

Thus, an affirmative necessary conditional entails a negative necessary conditional with the same antecedent and the consequent negated. Though the principle has been attributed to Boethius (d.524) it may in fact first have been formulated in the Latin tradition by Peter Abelard (d.1142). ${ }^{2}$ It was already clearly formulated by Avicenna a century earlier.

The reductio proof Avicenna offered for this view is as follows: Assume that (1) is true and (2) is false. Then the contradictory of (2) is true:

(3) Once (Qad yakun): If A is B then Not Every J is D

But (1) and (3) cannot both be true since this would mean that, assuming the antecedent 'Every A is B', it is at least once the case that 'Not Every $\mathrm{J}$ is $\mathrm{D}$ ' even though, by (1), 'Every $J$ is $D$ ' is always true when 'Every $A$ is $B$ ' is true. This is absurd. $^{3}$

2 See on this point Martin 1991, 303.

3 Ibn Sīnā, 1037a, 367-8. 
The prefixing of modal operators to conditionals may strike scholars familiar with the Latin logical tradition as odd. It is in fact distinctive of the Avicennian tradition of Arabic logic. Avicenna explicitly drew an analogy between these modal operators prefixed to conditional propositions and the quantifiers in categorical propositions. Proposition (1) is thus 'universal' while proposition (3) is 'particular'. These conditional 'quantifiers' are inter-definable just as the quantifiers of categorical propositions: 'Always' is equivalent to 'Not Once Not' and 'Once' is equivalent to 'Not Always Not'. ${ }^{4}$

Avicenna's claim that an affirmative-universal conditional entails a negativeuniversal conditional with the same antecedent and the contradictory consequent seems to have been accepted until the end of the twelfth century. Fakhr al-Dīn alRāzī (d.1210), for example, expounded it in his Mulakhkhaș in a manner suggesting that he did not find it problematic or controversial. ${ }^{5}$ In the early thirteenth century, however, the principle was challenged, and the ramifications of its denial explored. The first to do so seems to have been Afḍal al-Dīn al-Khūnajī (d.1248), a Persianborn scholar and judge in Ayyubid Egypt. ${ }^{6}$

Khūnajī argued as follows: the same antecedent may imply both a consequent and its contradictory. This can happen if the antecedent is impossible. Khūnaji argued that this is clear from the case of proofs by reductio:

\footnotetext{
${ }^{4}$ Ibn Sīnā 1037b, 254.

${ }^{5}$ Rāzī 1210, 232.

${ }^{6}$ I am preparing an edition of Khunaji's main work on logic Kashf al-asrār. I will defend my vocalization of the logician's name in the introduction.
} 
That something follows from something does not imply that its contradictory does not also follow from that thing, for a contradictory pair may follow from the same impossible antecedent. Is a reductio syllogism anything but a contradictory pair both following from the contradictory of the proposed conclusion? The contradictories of most claims in geometry, and for that matter in logic itself, imply both something and its contradictory. Scholarly works are full of proofs that show that a contradictory pair follows from the contradiction of a claim. This is not something obscure so that one needs to expand further. ${ }^{7}$

Najm al-Dīn al-Kātibī (d.1277), in his commentary on Khūnajī's work, did expand further. ${ }^{8}$ He explicated Khūnaji’s claim as follows: Suppose we wish to prove the following valid inference in the second-figure:
(1) Every $\mathrm{J}$ is $\mathrm{B}$
(2) No A is B
(3) No J is A

We assume the contradictory of the proposed conclusion:

(4) Some $\mathrm{J}$ is $\mathrm{A}$

\footnotetext{
7 Khūnajī 1248, fol.88v.

8 Kātibī 1277, fol. 145v.
} 
We then add the contradictory of the proposed conclusion to the two premises, and thus get an argument consisting of three premises. Premises (2) and (4) jointly imply (by FERIO):

(5) Some $\mathrm{J}$ is not B

But premise (1), viz. 'Every $\mathrm{J}$ is B', implies itself.

(6) Every $\mathrm{J}$ is $\mathrm{B}$

The three inconsistent premises (1) (2) and (4) together thus imply both 'Some $\mathrm{J}$ is not B' and 'Every $\mathrm{J}$ is B'.

For Khūnajī and his commentator Kātibī it was apparently too obvious to mention that by showing that an inconsistent set of premises implied both a proposition and its contradictory, they had also shown that the conditional having the premises as antecedent and the contradictory conclusions as consequent was true.

Khūnajī's rejection of Avicenna's principle was accepted by some later thirteenth century Arabic logicians. It was explicitly endorsed, for example, by Sirāj alDīn al-Urmawī (d.1283) in his influential advanced handbook of logic Matāli ${ }^{\prime}$ al-anwār, and by Athīr al-Dīn al-Abharī (d.1265) in his Tanzill al-afkār. ${ }^{9}$ It was also accepted by Ibn al-Muțahhar al-Hillī (d.1326) in his commentary on Tajrīd al-mantiq, a handbook 
on logic by his teacher Nașīr al-Dīn al-Ṭūṣī (d.1274) - this being one of the few occasions on which Hillī expressed disagreement with his teacher. ${ }^{10}$

In exploring some of the ramifications of Khūnajīs argument, a few contextual remarks may be helpful:

Medieval Arabic logicians in the Avicennist tradition - a tradition which had achieved a position of predominance by the thirteenth century and which includes all the logicians discussed here - distinguished between 'coincidental' (ittifāqi) and 'implicative' (/uzūmi) conditionals. The former were sometimes presented as being truth-functional, but then in the sense of being true if and only if both antecedent and consequent were true, or alternatively if and only if the consequent was true. The latter, which were clearly much more interesting to medieval Arabic logicians, were generally understood to involve a necessary connection - causal or conceptual between the antecedent and the consequent. Hence it could be false even if both antecedent and consequent were true. The necessary falsity of the antecedent was not sufficient for the truth of the conditional.

The same term, luzüm (which I translate as 'implication'), was used to denote both the relation between antecedent and consequent in a true 'implicative' conditional, and the relation between premises and conclusion in a valid argument. In 
other contexts, Arabic logicians did make the expected distinction between luzūm by virtue of form and luzūm by virtue of matter, and there is nothing to suggest that they failed to recognise that in the standard example of an 'implicative' conditional - 'If the sun is up then it is day' - the antecedent does not formally imply the consequent. However, they obviously did not think that it was always important to mark the distinction. Thus the antecedent in a true implicative conditional was said simply to 'imply' the consequent and the consequent to 'be implied by' the antecedent. Likewise, the premises in a valid argument was said to 'imply' the conclusion and the conclusion to be 'implied' by the premises. In what follows, I will follow the sources in using the term 'implication' in this broad sense, and not merely to denote formal implication.

As mentioned above, two modal operators - 'Always' and 'Once' - were prefixed to the conditionals. These were explicitly taken to correspond to the universal and particular quantifier in categorical propositions: a 'universal' conditional would hence look like this: 11

Always: If $\mathrm{P}$ then $\mathrm{Q}$

A 'particular' conditional would look like this:

Once: If $\mathrm{P}$ then $\mathrm{Q}$

11 For simplicity, I use propositional variables $(P, Q)$ and propositional constants $(p, q)$ in what follows. The sources do not do this, confining symbols to the level of terms, as in 'Always: If $A$ is $B$ then $J$ is $D$ '. 
These modal operators were thought to be logically related as the quantifiers of categorical propositions: 'Always' is equivalent to 'Not Once Not'; 'Not Always' to 'Once Not'; 'Once' to 'Not Always Not'. As is the case with categorical propositions, an affirmative-universal conditional was held to convert to an affirmative-particular proposition. Thus, the conditional 'Always: If this is a human then this is an animal' converted to 'Once: If this is an animal then this is human'.

In the 'particular' implicative conditional, the antecedent implies the consequent if conjoined with the truth of another proposition. For example, 'Once: If this is an animal then this is human' is true, since the truth of the antecedent 'This is an animal' will imply the truth of the consequent if we conjoin it to another proposition, such as 'This is rational'. By contrast, in the 'universal' implicative conditional, the truth of the antecedent alone implies (materially or formally) the truth of the consequent. An example would be the conditional 'Always: If this is human then this is an animal'. The truth of the consequent follows from the truth of the antecedent in all situations in which the antecedent is true, or to put it differently: the truth of the consequent follows from the truth of the antecedent alone, no matter if and how the antecedent is strengthened.

At this point, one of the ramifications of Khūnajīs argument becomes apparent. Avicenna had argued that it was strictly speaking false to say that, in a true universal implicative conditional, the consequent follows in all situations in which the antecedent is true. What about situations in which the antecedent is strengthened with another proposition that is inconsistent with the consequent? Surely that is a 
situation in which the original antecedent is true but the consequent does not follow? For example, the situation in which 'this is human' is true but 'this is not a self-moving and perceiving thing' is also true, is one in which it does not follow that 'this is an animal' is true. The characterisation should therefore be amended to be: the consequent follows in any possible situation in which the antecedent is true, or alternatively: the consequent follows the antecedent regardless of what propositions compatible with the antecedent are used to strengthen the antecedent.

Matters are a bit more complicated than this, since Avicenna drew a distinction between a conditional being true in fact ( $f$ nafs $a l-a m r)$ and its being supposed true for purposes of forcing a conclusion on an opponent in debate (bi'l-ilzām). For example: the conditional 'If 5 is even then it is a number' is true for purposes of argument, in the sense that someone who accepts the antecedent ' 5 is even' and the suppressed premise 'Everything that is even is a number', must accept the conclusion. It is false in fact because the antecedent and the suppressed premise are actually incompatible (since the even 5 is not a number, and no number is an even 5). Avicenna seems to have held that an affirmative conditional is only true fi nafs alamr if it can be reformulated as a true affirmative categorical proposition:

If our statement 'If five is even then it is a number' were true and should be conceded in itself, then it would be true to say "What is an even five is a number'. Since this is false, then the conditional that is equipollent to it must be false too. And if this categorical proposition [i.e. 'What is an even five is a 
number'] were true, then its converse - that some number is an even five would be true. ${ }^{12}$

The upshot of the distinction seems to be the following: The antecedent of a universal affirmative conditional that is true in fact must be at least possible. In this case, the objection that one may strengthen the antecedent with a proposition that is incompatible with the consequent cannot arise. For example, it cannot be objected to the universal truth of 'If 4 is even then it is a number' that one may strengthen the antecedent with the proposition ' 4 is not a number', in which case the consequent would not follow in all situations in which the antecedent is true. For the purported counter-example - and any other such counter-example - is false since it has an impossible antecedent. By contrast, a conditional that is true for the purpose of argument may have an impossible antecedent. To avoid the position that no universal conditional is true for the purpose of argument, since we can always strengthen the antecedent with a proposition that is not compatible with the consequent, we need to stipulate that the proposition used to strengthen the antecedent is compatible with it. ${ }^{13}$

Khūnajī seems to have ignored this distinction between a conditional being true in fact and for the purposes of argument, and he expressed reservations about Avicenna's proposed amendment. The impossible situation in which 'this is human'

\footnotetext{
12 Ibn Sīnā, 1037a, 240.

13 The distinction between truth fi nafs al-amrand bi'l-ilzām is introduced in Ibn Sīnā 1037a, 239-241. It is brought to bear on the problem of strengthening antecedents with propositions that are incompatible with the consequent in ibid, 273-275.
} 
and 'this is not an animal' are both true is not a situation in which it does not follow that 'this is an animal' is true. The impossible antecedent 'this is human \& this is not an animal' implies both the consequent 'this is an animal' and its contradictory 'this is not an animal'. As his commentator Kātibī put it:

We do not concede that if we assume the antecedent with the non-existence of the consequent then the consequent does not follow but instead the nonexistence of the consequent follows, nor that this [viz. that the non-existence of the consequent follows] necessitates the non-following of the consequent that is opposed to the affirmative implicative conditional. It is possible that both of a contradictory pair follow from an impossible antecedent. ${ }^{14}$

Similarly with the particular conditional: Such a conditional is true if the antecedent (formally or materially) implies the consequent when strengthened with another proposition. But unless we stipulate that the additional proposition must be compatible with the original antecedent, it would seem that any proposition will partially imply any other proposition, and that no universal-negative implicative conditional could be true. Khūnajī and Kātibī were - as we will see - willing to accept this conclusion.

Another ramification of Khūnajīs argument becomes apparent in the discussion of hypothetical syllogisms. Following Avicenna, the majority of Arabic logicians came to accept what they called 'conjoined' or 'combinatorial' (iqtirāni)

\footnotetext{
14 Kātibī 1277, fol. 140r.
} 
hypothetical syllogisms. A subclass of these conjoined hypothetical syllogisms is the syllogism consisting of two conditional premises in which the antecedent or consequent of one premise is an antecedent or consequent of the second. For example:

If $P$ then $Q$

If $Q$ then $R$

If $P$ then $R$

Such purely hypothetical syllogisms were contrasted with the so-called 'repetitive' (istithnā't) syllogisms - the latter corresponding to the familiar Stoic schemata in which a proposition mentioned in the conditional premise is affirmed or negated (and in this sense 'repeated') in the other premise.

Avicennian logicians claimed that the conditions for validity in hypothetical syllogisms of the type mentioned were identical to the conditions for the validity of categorical syllogisms. For example, if the consequent of the first premise was the antecedent of the second premise, then one had a first-figure syllogism that was valid if and only if the minor premise was affirmative and the major universal.

This had ramifications for Khūnajī's claim. As pointed out by Khūnajī's student Ibn Wāṣil al-Hamawī (d.1298), it was possible to defend Avicenna's principle by constructing an indirect proof in the third figure of the hypothetical syllogism: The truth of the universal conditional (1) 'Always: If $A$ is $B$ then $J$ is $D$ ' implied the truth of the negative universal conditional (2) 'Never: If A is B then $\mathrm{J}$ is not D'; otherwise the 
contradictory of the proposed negative universal conditional would be true (3) 'Once: If $A$ is $B$ then $J$ is not $D$ '. However, (1) and (3) imply (by FELAPTON) 'Once: If $J$ is $D$ then $\mathrm{J}$ is not $\mathrm{D}^{\prime}$. This conclusion is, or so the argument goes, absurd - being a contradiction of what has come to be known as Aristotle's Thesis ${ }^{15}$ that nothing is implied by its own negation. Ibn Wāṣil, following his teacher Khūnajī, responded by denying Aristotle's Thesis:

We say: We do not concede that our statement 'Once: If $\mathrm{J}$ is $\mathrm{D}$ then $\mathrm{J}$ is not $\mathrm{D}$ ' is false, since it may be the case that the antecedent is impossible and truly imply the impossible. ${ }^{16}$

Indeed, Khūnajī had adduced an independent argument to show that a particular affirmative conditional of the form 'Once: if $P$ then $Q$ ' is always true. ${ }^{17}$ Take any two propositions $\mathrm{p}$ and $\mathrm{q}$. It is possible to construct the following valid third-figure syllogism consisting of true premises:

Always: if $p \& q$ then $p$

Always: if $p \& q$ then $q$

Once: if $p$ then $q$

\footnotetext{
15 McCall, 1966.

16 Ibn Wāsil 1298, fol. 47v.

17 Khūnaj̄i 1248, fol. 126v.
} 
If one accepts that an impossible antecedent may imply both a consequent and its contradictory, then it ceases to matter whether $p$ and $q$ are incompatible or contradictory. It is thus possible to formulate the argument as follows: 18

\author{
Always: if $P$ \& not- $P$ then $P$ \\ Always: if $P \&$ not- $P$ then not- $P$ \\ Once: if $P$ then not- $P$
}

III

The argument constructed by Khūnajī was obviously viewed as paradoxical by many later logicians. The late fourteenth-century Persian scholar al-Sayyid al-Sharif alJurjānī (d.1413), in a work that was probably read by most students in the Islamic world for half a millennium, gave a summary of the problem:

In this connection the following point has been established: It can be said that one of three things must be the case: (i) Either the whole does not imply the part; (ii) or a third-figure syllogism consisting of conditional premises is invalid; or (iii) a partial implication obtains between any two facts whatsoever and it 
follows that the universal negative implicative conditional is not true regardless of the matter. ${ }^{19}$

Most of the later logicians who were unhappy with Khūnajīs argument chose to accept the first of the seemingly paradoxical options listed by Jurjānī. Nașîr al-Dīn alṬūṣi (d.1274), for example, rejected the position that a conjunctive antecedent implies either conjunct:

The following of a part from a sum of parts is not a true instance of implication but is rather a repeated utterance. If we say 'If this is a writer and a laugher' we do not doubt that his being a writer does not necessitate his being a laugher, and has no connection with it ... so its occurrence in the antecedent is, with regards to implication, extrinsic and superfluous (ajnabiyyun wa hashwun mahọ) ... Thus the proposition is really tantamount to saying 'If this is a laugher [then this is a laugher]' which is like saying 'The laugher is a laugher' - neither deserves to be considered a proposition. ${ }^{20}$

Ṭūṣi thus distinguished between the uttered antecedent and the real antecedent. He used this distinction to diagnose what was wrong with the paradoxical hypothetical third-figure syllogism:

\footnotetext{
19 Jurjānī 1413, 137.

20 Ṭūṣī 1274, 173.
} 
Always: If this is a human and a horse then this is a human

Always: If this is a human and a horse then this is a horse

Once: If this is a human then this is a horse

In the first premise it is the first conjunct of the antecedent (this is a human) that alone implies the consequent, and the second conjunct (this is a horse) is irrelevant to the obtaining of the consequent. Similarly, in the second premise it is the second conjunct of the antecedent (this is a horse) alone that implies the consequent, and the first conjunct (this is a human) is irrelevant. The fact that a middle term is mentioned (yatakarrar lafzan) is misleading. On the level of 'meanings' or 'intentions' ( ma'āni) there is no middle term. ${ }^{21}$

The diagnosis does not itself reveal whether Ṭusși believed that the premises of the hypothetical syllogism are false or whether they are true but do not 'really' have a middle term. The following analogy that he drew with categorical syllogisms clearly shows that he believed the premises to be false: By the same token, he argued, one should be able to construct the following categorical syllogism in the third figure:

Every human and horse is a human

Every human and horse is a horse

Some humans are horses 
The conclusion is clearly false, and since Ṭūṣī explicitly stated that the syllogism was formally valid, he must have held the premises to be false. His diagnosis of the problem is analogous to the case of the troublesome hypothetical syllogism: in the first premise, it is the first conjunct of the subject-term (human) that calls for an affirmative relation to the predicate, and in the second premise it is the second conjunct (horse). There is no middle term except in utterance.

Ṭușị's analogy with a categorical syllogism in the third-figure seems, at least at first sight, to overlook a significant difference between categorical and conditional propositions. It was generally agreed that affirmative categorical propositions have existential import, and hence are not true if the subject does not exist, actually or possibly. Kātibī mentioned precisely the same third-figure categorical syllogism, and he too believed the syllogism to be formally valid and the conclusion false. His diagnosis of the problem with the premises, however, was different and arguably more straightforward: they are both false since there is nothing corresponding to the subject-terms. ${ }^{22}$ By contrast, it was generally accepted that conditionals could be true even if their antecedent was impossible. Țūșī, however, argued that impossible antecedents should, strictly speaking, be treated analogously to impossible subjects. Strictly speaking, nothing follows from impossible antecedents, just as nothing can be predicated of impossible subjects.

The impossible (al-muhāâ) insofar as it is impossible, and even the non-existent insofar as it is non-existent, cannot be judged to imply something, but can be

\footnotetext{
22 Tahtānī 1365b, 169.
} 
judged not to imply something. Just as the subject, insofar as it does not exist, cannot be the subject of an affirmative judgement, but all things can be negated of it. 23

Ṭūṣi's position is more flexible than this quotation suggests, since he accepted Avicenna's distinction between conditionals being true de facto and being true for the purposes of argument. A conditional cannot be true de facto if it has an impossible antecedent, but it may still be true for the purposes of argument. His diagnosis is meant to disarm the conclusion when the premises are taken as true in the latter sense.

Ṭūṣi was also dismissive of attempts to question Avicenna's principle that an affirmative universal conditional (Always: If $P$ then $Q$ ) implied a negative universal conditional with the same antecedent and the negated consequent (Never: If $P$ then not-Q). In his Ta'dil al-mi'yār he tried to rebut the following statement by Athīr al-Dīn al-Abharī (d.1265): 'The mind cannot be certain that implying a negation implies the negation of implication, for the antecedent of the conditional could be impossible, and the impossible may imply two contradictories'. In other words, Abharī - presumably following Khūnaji - doubted whether 'If $P$ then not- $Q$ ' implied 'Not: If $P$ then $Q$ ', since if the antecedent $P$ is impossible then it could imply both not- $Q$ and $Q$. To this, Țūṣi replied:

\footnotetext{
23 Ṭūṣī 1274, 171.
} 
If an impossible antecedent's implying two contradictories were to undermine [the principle] that the implication of a negative [consequent] implies the negation of the implication of an affirmative [consequent] - by its being the case that it both implies the negation of the implication of the affirmative [consequent] (insofar as it necessitates the implication of the negative [consequent]) and does not imply it (insofar as it necessitates the implication of the affirmative [consequent]) - then it should firstly undermine the very implication of the negative [consequent] that is conjoined with the implication of the affirmative [consequent]. For the following of two opposing [propositions] is the cause of this conjoining of implication and non-implication, and undermining the corrupt effect and not the cause that necessitates it is indefensible. ${ }^{24}$

Abharī took the position that 'If $P$ then not- $Q$ ' and 'If $P$ then $Q$ ' can both be true in case $P$ is impossible, and that this shows that implying a negation (If $P$ then not- $Q$ ) is not logically equivalent to not implying (Not: If $P$ then $Q$ ). To this Țūși responded by arguing that to accept that 'If $P$ then not- $Q$ ' and 'If $P$ then $Q$ ' could both be true should be taken as showing that neither not- $\mathrm{Q}$ nor $\mathrm{Q}$ are implied by the antecedent $\mathrm{P}$. The possibility that the same antecedent $P$ can imply both $Q$ and not- $Q$ should undermine the very principle of universa/implication.

Rather, what should be rejected here is implication itself, because of the possibility of the implication of two contradictories. Instead of what he [Abhari] 
said, he should have said, 'The mind cannot be certain (Iā jazma li'/'aql) of something being implied by something in the first place, for the antecedent of the conditional may be impossible, and the impossible may imply two contradictories'. In this manner, the door of implication would be closed universally (bi'l-kulliyah). ${ }^{25}$

Ṭūṣi thus argued that if Abharī were right, and 'If $P$ then not- $Q$ ' and 'If $P$ then $Q$ ' could both be true, then there would not be such a thing as universal ( $k u l / I)$ implication, and any conditional of the form 'Always: if P then Q' would be false.

IV

Ṭușịs rejection of the idea that an antecedent could imply both a proposition and its contradictory, and his diagnosis of what was wrong with the problematic third-figure hypothetical syllogism of Khūnajī, had a significant impact on the later logical tradition.

On the first of these points: it seems to have been because of criticisms such as Ṭūṣīs that Abharīs student Kātibī, who is known to have corresponded with Ṭūṣi on philosophical and logical matters, presented a somewhat modified account of Khūnajī's and Abharīs position. ${ }^{26}$ In his commentary on Khūnajī's Kashf al-asrār,

\footnotetext{
25 Ṭūșī 1274, 170.

${ }^{26}$ Many modern scholars, including N. Rescher in his The Development of Arabic Logic (Rescher 1964, 203-4), have been misled by the statement of the $17^{\text {th }}$ century Ottoman bibliographer Katip Çelebi (d.1657) to the effect that Kātibī was Ṭūṣìs student. Kātibī was, by his own testimony, a student
} 
Kātibī held that Khūnajī's criticism of Avicenna overlooked Avicenna's distinction between a conditional being true in fact ( $f$ nafs $a l-a m r)$ and for the purpose of argument (bil'-ilzām). He pointed out that it was specifically of conditionals being true in the second sense that Avicenna had insisted that the situations relevant to the truth of the universal conditional be those compatible with the antecedent. Unless we made this specification, accepting the antecedent would not commit someone to also accepting the consequent, and thus no universal conditional would be true bi'l-ilzām:

In other words, we shall not be able to force someone to concede its [the conditional's] truth. For if for example we claim that it is true that 'Always: If this is human...', in any situation or with any supposition, regardless of whether this situation or condition possibly coexists with it [the antecedent] or not '...then it is an animal', then it will be said: We do not concede its truth in the manner you have claimed, for one of the situations and conditions is not being an animal ('adam al-hayawaniyya) or being an animal not following from it ('adam luzūm al-hayawāniyya iyyāh). If you take it [the conditional] with these two considerations, then we do not concede that being an animal is implied by it [the antecedent]. ${ }^{27}$

Kātibī agreed with Avicenna (and Țūṣī) on this point. He also agreed with Avicenna that this stipulation was not necessary in the case of universal conditionals that were

of Abhari's. Katip Çelebi seems not to have been particularly well-informed on this point, and the date of death that he gives for Kātibīi is obviously a guess and in fact two decades off the mark.

27 Kātibī 1277, fol.139v. 
true in fact. Such conditionals remain true regardless of how we strengthen the antecedent. The de facto truth of 'Always: If the sun is up then it is day' is not affected by situations that are incompatible with the antecedent (such as 'The sun is up and it is not day') that could be used to construct a counterexample to the original conditional ('Always: If the sun is up and it is not day then it is not day'). Avicenna defended this position by claiming that any such counter-example with 'strengthened' antecedent and contradictory consequent would be false, since the 'strengthened' antecedent was impossible, and any conditional with an impossible antecedent was de facto false. Kātibīs reason for rejecting such counterexamples was different - he may have wished to allow for conditionals that had an impossible antecedent but were nevertheless de facto true. Instead, he followed Khūnajī in maintaining that the conditionals with strengthened and impossible antecedents simply did not contradict the original conditional:

If someone were to falsify the truth of the universal conditional that is true in fact ... as when someone says: 'It is not true that whenever the sun is up then it is day', and argues that if we take the sun being up with its not being day, or with it not following that it is day, then it does not follow that it is day - we deny that this [counter-] conditional is true. And if he claims that not being day follows it in such cases, then we concede this and deny that it contradicts our statement 'Always: if the sun is up then it is day'. All that we concede is that if both conditionals are true then its being day and its not being day both follow from the sun being up in some situations and according to some suppositions. 
However, it is not known that this is impossible, since it is possible that these situations and suppositions are impossible, and it is not excluded that an impossibility implies another impossibility. ${ }^{28}$

Why did Kātibī not use the same Khūnaj̄i-inspired diagnosis for purported counterexamples to universal conditionals that are held to be true bi'l-ilzām? He seems to have reasoned as follows: A universal conditional that is true bi'l-ilzām is such that someone who accepts the antecedent must be able to see that she must also accept the consequent. Suppose we put forward such a universal conditional: 'Always: If P then Q'. A counter-example to the universal truth of such a conditional would be: 'Always: If $P$ and not- $Q$ then not- $Q$ '. In this dialectic context, it would not do to concede that the counterexample is true but does not contradict the original conditional, for the counterexample does not contradict the original conditional only if the original conditional is universally true, and this is precisely the point at issue. By conceding the truth of the counterexample, we have cast doubt on the truth of the original universal conditional, and shall not be able to show that someone who accepts the antecedent must also accept the consequent.

If we claim that it is true that 'Always: if a number is two then it is even' without adding the condition that the situations and conditions that are supposed to obtain be compatible with it but rather unconditionally ... and it is said [in objection]: one of these situations is it [the number two] not being divisible into 
equals, and if you take it [the conditional] with this supposition then we do not concede that being even is implied by it [the number two] ... Thus there are situations such that if we suppose them to obtain with the antecedent of the conditional then the following of the consequent in such cases would be unknown ... and hence it is not the case that whenever we suppose the antecedent to obtain we can say with certainty (najzim) that the consequent follows. ${ }^{29}$

A similar line was taken by Shams al-Dīn al-Samarqandī (fl. 1283-91) in his commentary on his own summa of logic Qusțās al-afkār. Discussing Avicenna's stipulation that the situations relevant to assessing the truth of the universal affirmative conditional are those compatible with the antecedent, Samarqandī wrote:

They have objected to Avicenna that we do not concede that the consequent does not follow the antecedent if we suppose the antecedent with the nonobtaining of the consequent or with the non-following of the consequent. At most, the non-obtaining of the consequent, or the non-following of the consequent, follows [such strengthened antecedents] but it does not follow from this that the [original] consequent does not follow from the [original] antecedent. It is possible that something imply two contradictories if that thing is impossible. The conjunction of that which implies something and the contradictory of that 
[implied] thing implies both that which implies something and its contradictory, as is the case in reductio syllogisms. ${ }^{30}$

Having presented Khūnajīs objection, Samarqandī proceeded to present Kātibī's modified defense of Avicenna's stipulation:

The answer is that what is claimed is that if it is not stipulated that the these matters [the situations that are supposed to obtain with the antecedent] are compatible with the antecedent, then one cannot say with certainty (lam yahșul al-jazm) that the conditional is true as a universal. If we suppose the nonobtaining of the consequent, or the non-following of the consequent, to obtain with the antecedent, then it may be that the consequent does not follow from it [the original antecedent], for the impossible antecedent may imply two contradictories, but does not necessarily do so ... With this possibility it is not possible to say with certainty (imtana'a al-jazm) that the conditional is true as a universal. It is thus known that it must be stipulated that these matters [viz. the situations that are supposed to obtain with the antecedent] be compatible with the antecedent. 31

Ṭusșis diagnosis of what was wrong with the problematic third-figure hypothetical syllogism of Khūnajī was also echoed in later Arabic logical writings. It

\footnotetext{
30 Samarqandī 1283-91, fol. 81v

31 Samarqandī 1283-91, fol.82r.
} 
was cited, for example, by the fourteenth-century North African scholar Muhammad al-Sharîf al-Tilimsānī (d.1370), one of the teachers of the well-known historian Ibn Khaldūn (d.1406), in his commentary on Khūnajī's shortest work on logic al-Jumal. Al-Sharīf al-Tilimsānī quoted verbatim from Ṭūșị’s Ta'dīl al-mi'yār and noted that this was the counter-argument to Khūnajī of 'those who are inordinately partisan to Avicenna (al-muta'așșibūn li'l-Shaykh)'. ${ }^{32}$

Ṭūṣi's arguments were also echoed by the very influential Timurid scholar, Sa'd al-Dīn al-Taftāzānī (d.1390). Commenting on the following two conditionals that could be adduced to show that an antecedent may imply both a proposition and its contradictory:

Always: If something is human and non-human then it is human

Always: If something is human and non-human then it is non-human

Taftāzānī wrote:

We do not concede that the two premises are true. They would be true if each part of the antecedent were relevant to the obtaining of the implication (dakh/ fi iqtid̄ẩ al-luzūm). It is clear that humanity has nothing to with the implication of non-humanity, nor has non-humanity anything to do with the implication of humanity. Yes, this would be true with respect to what one is forced to concede 
(bi-hasab al-ilzām) but we are speaking of what is true in fact (bi-hasab nafs alamr). 33

However, Khūnajī's argument was by no means universally rejected in later centuries. It was accepted, for example, by Mas'ūd al-Shirwānī (d.1499) in his influential commentary on the widely used handbook on dialectic (ādāb al-bahth) by the previously mentioned Shams al-Dīn al-Samarqandī. Shirwānī wrote:

Between any two facts (amrayn), even contradictories, there is a partial implication. This has been shown by a proof in the third figure: Whenever the collective (majmū) of two facts obtains then one of them obtains. Whenever the collective obtains the other obtains. This produces: It may be that if one of the two obtains the other obtains. ${ }^{34}$

\section{V}

Neither those who embraced Khūnajī's arguments, nor those who opposed them, seem to have countenanced the principle that anything follows from an impossible

\footnotetext{
33 Taftāzānī 1390, p. 110.

${ }^{34}$ Shirwānī 1499, fol.8r. The influence of this work is clear from the bibliographic compilation of the Ottoman scribe Katip Çelebi, who states that Samarqandi's treatise was the most used handbook on dialectic in his time, and that Masūd al-Shirwānīs commentary on it was the best-known of the commentaries, and itself became the subject of several super-commentaries by later scholars. See Katip Çelebi 1657, 1:207.
} 
proposition. Khūnajī's paradoxical third-figure hypothetical syllogism is phrased in a manner that does not explicitly challenge the assumption that there must be some relevance between premises and conclusion or between antecedent and consequent in an implicative conditional. Yet even the principle of 'simplification' that he used (i.e. inferring either conjunct from a conjunction), and the principle of 'monotonicity' that he defended (i.e. that if premises implied a conclusion they would do so regardless of what propositions were added to the premises), were too much for many later Arabic logicians. Following Ṭusșī, they rejected simplification and demanded that all conjuncts in the antecedent be relevant to the obtaining of the consequent - and that all premises in an argument be relevant to the conclusion - before they would concede that this constituted a true implicative conditional, or a valid inference. 


\section{ACKNOWLEDGMENTS}

An earlier version of this paper was delivered at a conference on "Aristotelian logic, East and West, 500-1500: The Topics" at the University of Cambridge in March 2006. I would like to thank the participants for their helpful comments and queries. I would also like to thank Tony Street, Stephen Read, and two anonymous readers for $H L P$ for their helpful comments on an earlier draft. The responsibility for remaining shortcomings lies, of course, with me alone. 


\section{BIBLIOGRAPHY}

Ibn Sīnā 1037a. al-Shifā' 4: al-Qiyās, ed. S. Zāyid, Cairo; Ministry of Culture, 1964.

Ibn Sīnā. 1037b. al-Ishārāt wa'l-tanbīhāt, ed. S. Dunya, Cairo; Dar al-Ma'arif, 1960.

al-Hillī, Ibn al-Muțahhar, 1325. al-Jawhar al-nadị fi Sharh manțiq al-Tajríd, ed. M. Bidarfar, Qom; Intisharat Bidar, 1423H.

Ibn Wāṣil al-Ḥamawī 1298. Sharh al-Jumal, MS; Yale University (Beinecke); Landberg 104).

Jacobi, K. ed. 1993. Argumentationstheorie: Scholastische Forschungen zu den logischen und semantischen Regeln korrekten Folgerns, Leiden; EJ Brill.

al-Jurjani, al-Sayyid al-Sharîf 1413. Hāshiya ála Sharh al-Shamsiyyah [printed (on the lower part of the page) with Taḥtānī, Tahrīir al-qawāíid.

Katip Çelebi 1657. Kashf al-ẓunūn 'an asāmi al-kutub wa'l-funūn, ed. G. Fluegel, Leipzig; Oriental Translation Fund, 1835.

al-Kātibi, Najm al-Dīn 1277. Sharh Kashf al-asrār, MS; Suleymaniye; Carullah 1417. 
al-Khūnaj̄i, Afdal al-Dīn 1248. Kashf al-asrār 'an ghawāmị al-afkār, MS; Suleymaniye; Carullah 1435.

Martin, C. 1986. 'William's Machine', Journal of Philosophy 83, 564-572.

Martin, C. 1987. 'Embarrassing arguments and surprising conclusions in the development of theories of the conditional in the twelfth century', in Gilbert de Poitiers et son contemporains, ed. J. Jolivet and A. de Libera, Napoli; Bibliopolis, 377-401;

Martin, C. 1991. 'The logic of negation in Boethius', Phronesis 36, 277-304.

McCall, S. 1966 ‘Connexive Implication’, Journal of Symbolic Logic 31, 415-433.

al-Rāzī, Fakhr al-Dīn 1210. Manțiq al-Mulakhkhaș, ed. A.F. Karamaleki \& A. Asgharinezhad, Tehran; ISU Press, $1381 \mathrm{H}$.

Rescher, N. 1964. The Development of Arabic Logic, Pittsburgh; University of Pittsburgh Press.

al-Samarqandī, Shams al-Dīn 1283-91. Sharh Qusțās al-afkār, MS; Berlin Staatsbibliothek; Landberg 1035. 
al-Shirwānī, Mas'ūd 1499. Sharh al-Ādāb al-Samarqandiyya, MS; British Library; Or.3124.

al-Taftāzānī, Sa'd al-Dīn 1390. Sharh al-Shamsiyya, Lithograph; Istanbul; Hasan Hilmi Rizavi, 1312H.

al-Taḥtānī, Qutb al-Dīn al-Rāzī 1365a. Lawāmic al-asrār Sharh Mațāli al-anwār, Istanbul; Dār al-Tibāaca al-'Āmira, 1277H.

al-Taḥtānī, Qutb al-Dīn al-Razi 1365b. Tahrīr al-qawāid al-mantiqiyya bi-Sharh alRisāla al-Shamsiyya, Cairo; Mustafa al-Babi al-Halabi, 1948.

al-Tilimsānī, Muḥammad al-Sharif 1370. Sharh al-Jumal, MS; British Library; Add. 9617.

al-Ṭuș̣ī, Nașīr al-Dīn 1274. Ta'dil al-mi'yār fi naqd Tanzill al-afkār, in Collected Texts and Papers on Logic and Language, ed. M. Mohaghegh and T. Izutsu, Tehran; Institute of Islamic Studies, McGill University, Tehran Branch, 1974 (Wisdom of Persia 8). 